\title{
A nanocrystalline MgO support for Ni catalysts for steam reforming of $\mathrm{CH}_{4}$
}

\author{
Mahmood ANDACHE a, Mehran REZAEI b,*, Mansour KAZEMI MOGHADAM c \\ a Department of Chemistry, Islamic Azad University, Omidiyeh Branch, Omidiyeh, Iran \\ ${ }^{\mathrm{b}}$ Catalyst and Advanced Materials Research Laboratory, Chemical Engineering Department, Faculty of Engineering, University of Kashan, Kashan, Iran \\ ${ }^{c}$ Chemical Engineering Department, Iran University of Science and Technology, Tehran, Iran
}

\section{A R T I C L E I N F O}

Article history:

Received 23 February 2013

Accepted 28 April 2013

Published 20 July 2013

Keywords:

Steam reforming

Carbon deposition

Nickel-magnesia solid solution

\begin{abstract}
A B S T R A C T
Nanocrystalline $\mathrm{MgO}$ with a relatively high surface area and mesoporous structure was synthesized by a surfactant assisted precipitation method for use as the support of nickel catalysts for steam reforming of methane. The samples were characterized by X-ray diffraction, $\mathrm{N}_{2}$ adsorption, temperature-programmed reduction, temperature-programmed oxidation, scanning electron microscopy, and transmission electron microscopy. The catalysts showed high catalytic activity and good stability in the steam reforming of methane. Increasing the nickel loading up to $10 \mathrm{wt} \%$ gave increased activity. Catalysts with higher nickel loadings showed more deposited carbon after reaction. The excellent anti-coking performance of the catalysts was attributed to the formation of a nickel-magnesia solid solution, basicity of the support surface, and nickel-support interaction.
\end{abstract}

(C) 2013, Dalian Institute of Chemical Physics, Chinese Academy of Sciences. Published by Elsevier B.V. All rights reserved.

\section{Introduction}

The reforming of methane with steam is used in industry for synthesis gas production [1]. In this process, different catalysts have been used. Deactivation of nickel catalysts as a result of carbon deposition is a main problem in this process [2]. Although carbon deposition is affected by many factors, the two important properties are surface acidity and surface structure. Coke formation on larger nickel particles occurs easily, which deactivates nickel active sites. In addition, acidic supports can lead to carbon deposition.

It has been suggested that the use of a catalyst support with a low concentration of Lewis acid sites would decrease coke formation [3,4]. MgO is widely selected as a catalyst support because of its high thermal stability and low cost [5-8]. The surface areas of metal oxide powders at high temperatures depend on their melting point and occurrence of phase trans- formation. $\mathrm{MgO}$ has a very high melting point $\left(2850^{\circ} \mathrm{C}\right)$, which can allow $\mathrm{MgO}$ to maintain a relatively large surface area at high temperatures when compared to most other oxides used as a catalyst support. Furthermore, $\mathrm{MgO}$ and $\mathrm{NiO}$ both have a face centered cubic structure with almost the same lattice parameters, $4.2112 \AA$ for $\mathrm{MgO}$ and $4.1684 \AA$ for $\mathrm{NiO}$. As a result, the interaction of $\mathrm{MgO}$ and $\mathrm{NiO}$ leads to the formation of a solid solution (NiO-MgO) [8], on which only a small amount of $\mathrm{NiO}$ in the solid solution can be reduced, leading to very small Ni particles. The very small sized Ni particles play an important role in inhibiting carbon deposition [9]. Therefore MgO with high basicity would be an appropriate support to prevent coke formation. In this work, plate-shaped nanocrystalline MgO with a high surface area was synthesized and used as the support for nickel catalysts for the steam reforming of methane.

\section{Experimental}

\footnotetext{
*Corresponding author. Tel: +98-361-5912469; Fax: +98-361-5559930; E-mail: rezaei@kashanu.ac.ir This work was supported by Islamic Azad University, Omidiyeh Branch. 


\subsection{MgO preparation}

Polyvinyl alcohol (PVA, $M_{\mathrm{r}}=72000$ ) was dissolved in water at $90{ }^{\circ} \mathrm{C}$ under vigorous stirring to form a transparent solution. $\mathrm{Mg}\left(\mathrm{NO}_{3}\right)_{2} \cdot 6 \mathrm{H}_{2} \mathrm{O}$ was dissolved in this solution. The metal ion to PVA monomer molar ratio (Mg/PVA) was 1:3. Aqueous ammonia $(25 \mathrm{wt} \%)$ was added dropwise at room temperature to the resulting viscous liquid mixture under rapid stirring and careful $\mathrm{pH}$ adjustment to 10.5. After precipitation, the slurry was stirred for another $30 \mathrm{~min}$ and then refluxed at $80{ }^{\circ} \mathrm{C}$ for $20 \mathrm{~h}$ under continuous stirring. The mixture was cooled to room temperature, filtered, and washed with hot deionized water to remove polyvinyl alcohol. The final product was dried at $80{ }^{\circ} \mathrm{C}$ for $24 \mathrm{~h}$ and calcined at $700{ }^{\circ} \mathrm{C}$ for $4 \mathrm{~h}$.

\subsection{Catalyst preparation}

$\mathrm{Ni}$ catalysts supported on $\mathrm{MgO}$ were prepared by impregnation using an aqueous solution of $\mathrm{Ni}\left(\mathrm{NO}_{3}\right)_{2} \cdot 6 \mathrm{H}_{2} \mathrm{O}$. After impregnation, the sample was dried at $80{ }^{\circ} \mathrm{C}$ and calcined at 500 ${ }^{\circ} \mathrm{C}$ for $4 \mathrm{~h}$ in static air atmosphere.

\subsection{Characterization}

The surface areas (BET) were determined by nitrogen adsorption at $-196{ }^{\circ} \mathrm{C}$ using an automated gas adsorption analyzer (Tristar 3020, Micromeritics). The X-ray diffraction (XRD) patterns were recorded on an X-ray diffractometer (PANalytical $\mathrm{X}$, Pert-Pro) in the range $2 \theta=10^{\circ}-80^{\circ}$. Temperature-programmed reduction ( $\mathrm{H}_{2}$-TPR) was performed in an automatic apparatus (Chemisorb 2750, Micromeritics) equipped with a thermal conductivity detector (TCD). The fresh catalyst (200 mg) was pretreated with a heat treatment (10 ${ }^{\circ} \mathrm{C} / \mathrm{min}$ ) in a gas flow (40 $\left.\mathrm{ml} / \mathrm{min}\right)$ of $10 \% \mathrm{H}_{2} / \mathrm{Ar}$. Temperature-programmed oxidation (TPO) of spent catalysts was performed in the same apparatus by introducing a gas flow (30 $\mathrm{ml} / \mathrm{min}$ ) of $5 \% \mathrm{O}_{2} / \mathrm{He}$ over $50 \mathrm{mg}$ of spent catalyst and the temperature was increased at a heating rate of $10{ }^{\circ} \mathrm{C} / \mathrm{min}$. Surface morphology of the samples was investigated by scanning electron microscopy (SEM, Vega@Tescan) and transmission electron microscopy (TEM, JEOL JEM-2100UHR).

\subsection{Catalyst evaluation}

Activity measurements were carried out in a fixed-bed continuous flow reactor made of $7 \mathrm{~mm}$ i.d. quartz tube at atmospheric pressure. The reactor was charged with $200 \mathrm{mg}$ catalyst. Prior to the reaction, the catalyst was reduced at $750{ }^{\circ} \mathrm{C}$ for $8 \mathrm{~h}$ in flowing $\mathrm{H}_{2}(30 \mathrm{ml} / \mathrm{min})$ and cooled to $600{ }^{\circ} \mathrm{C}$ in a flow of $\mathrm{Ar}$ (30 ml/min). After that, a reactant gas consisting of a mixture of $\mathrm{CH}_{4}$ and steam was introduced into the reactor, and the activity test was performed at temperatures ranging from 600 to 750 ${ }^{\circ} \mathrm{C}$ in steps of $50{ }^{\circ} \mathrm{C}$ with $60 \mathrm{~min}$ at each temperature. The loss in catalyst activity at $700{ }^{\circ} \mathrm{C}$ was monitored for $50 \mathrm{~h}$ time on stream. The gas composition of reactants and products was analyzed using a gas chromatograph equipped with a TCD and a Carboxen 1000 column.

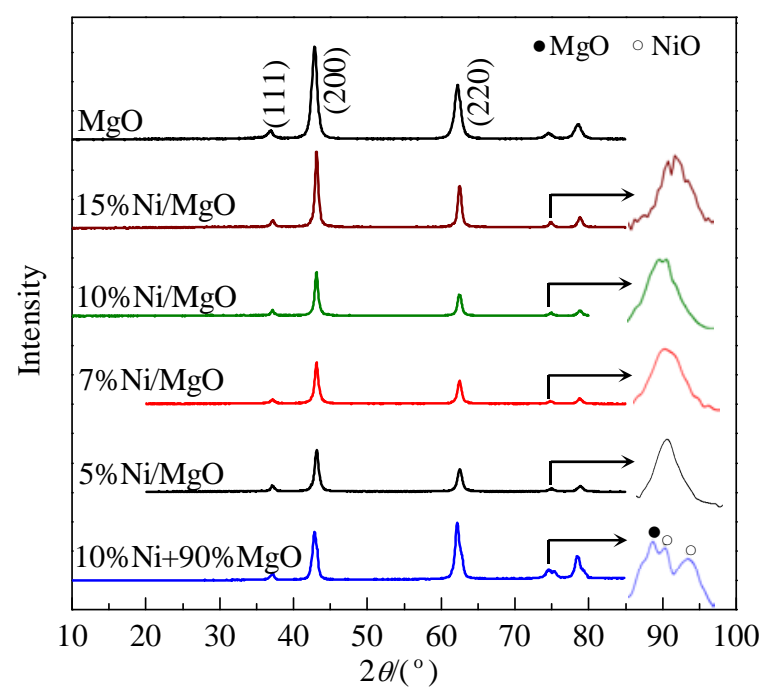

Fig. 1. XRD patterns of calcined $\mathrm{Ni} / \mathrm{MgO}$ catalysts and $\mathrm{MgO}$ support.

\section{Results and discussion}

Figure 1 shows the XRD pattern of the synthesized MgO powder. All the XRD peaks can be assigned to pure periclase MgO phase. The lattice parameter of MgO was $a=4.21 \AA$, in good agreement with JCPDS PDF data (No. 45-946) [10]. In the XRD patterns of the $\mathrm{Ni} / \mathrm{MgO}$ catalysts in Fig. 1, the peaks assigned to $\mathrm{NiO}$ and $\mathrm{MgO}$ in the $10 \% \mathrm{Ni}+90 \% \mathrm{MgO}$ physical mixture changed into one peak for $10 \% \mathrm{Ni} / \mathrm{MgO}$, indicating the formation of a solid solution of $\mathrm{NiO}$ and $\mathrm{MgO}$. The XRD patterns of the catalysts with $5 \%$ and $7 \%$ nickel also showed one peak at $74.5^{\circ}$, indicating the formation of a $\mathrm{NiO}-\mathrm{MgO}$ solid solution. The increasing intensity of the diffraction peaks with increasing nickel content indicated that there was an increase in the crystallite size of the solid solution.

The structural properties of the $\mathrm{Ni} / \mathrm{MgO}$ catalyst support and calcined $\mathrm{Ni} / \mathrm{MgO}$ catalysts are presented in Table 1 . The MgO catalyst support showed a relatively high surface area and nanocrystalline structure. The specific surface area decreased with increasing Ni content for catalysts with nickel loadings higher than $7 \%$. The $\mathrm{N}_{2}$ adsorption profiles for the calcined $\mathrm{Ni} / \mathrm{MgO}$ catalysts are shown in Fig. 2(a). The $\mathrm{N}_{2}$ isotherms were type IV with a large type $\mathrm{H}_{3}$ hysteresis loop. This type of hysteresis is usually found with solids consisting of agglomerates of particles that form slit shaped pores (plates or particles with edges, like cubes) with a non-uniform size and/or shape. The

Table 1

Structural properties of the catalyst support $\mathrm{MgO}$ and $\mathrm{Ni} / \mathrm{MgO}$ catalysts.

\begin{tabular}{|c|c|c|c|c|c|c|}
\hline \multirow[t]{2}{*}{ Sample } & \multicolumn{2}{|c|}{$A_{\mathrm{BET}}\left(\mathrm{m}^{2} / \mathrm{g}\right)$} & \multicolumn{2}{|c|}{$\begin{array}{c}\text { Pore volume } \\
\left(\mathrm{cm}^{3} / \mathrm{g}\right)\end{array}$} & \multicolumn{2}{|c|}{ Pore size (nm) } \\
\hline & Fresh & Spent & Fresh & Spent & Fresh & Spent \\
\hline $\mathrm{MgO}$ & 72.4 & - & 0.19 & - & 15.2 & - \\
\hline $5 \% \mathrm{NiO} / \mathrm{MgO}$ & 44.4 & 28.3 & 0.24 & 0.23 & 12.1 & 16.0 \\
\hline $7 \% \mathrm{NiO} / \mathrm{MgO}$ & 63.4 & $23.0^{\mathrm{a}}$ & 0.23 & $0.18^{\mathrm{a}}$ & 14.6 & $22.8^{\mathrm{a}}$ \\
\hline $10 \% \mathrm{NiO} / \mathrm{MgO}$ & 51.5 & 40.7 & 0.26 & 0.18 & 12.5 & 16.1 \\
\hline $15 \% \mathrm{NiO} / \mathrm{MgO}$ & 46.5 & 27.7 & 0.26 & 0.24 & 12.9 & 17.7 \\
\hline
\end{tabular}

a Spent catalyst after $50 \mathrm{~h}$ time on stream. 

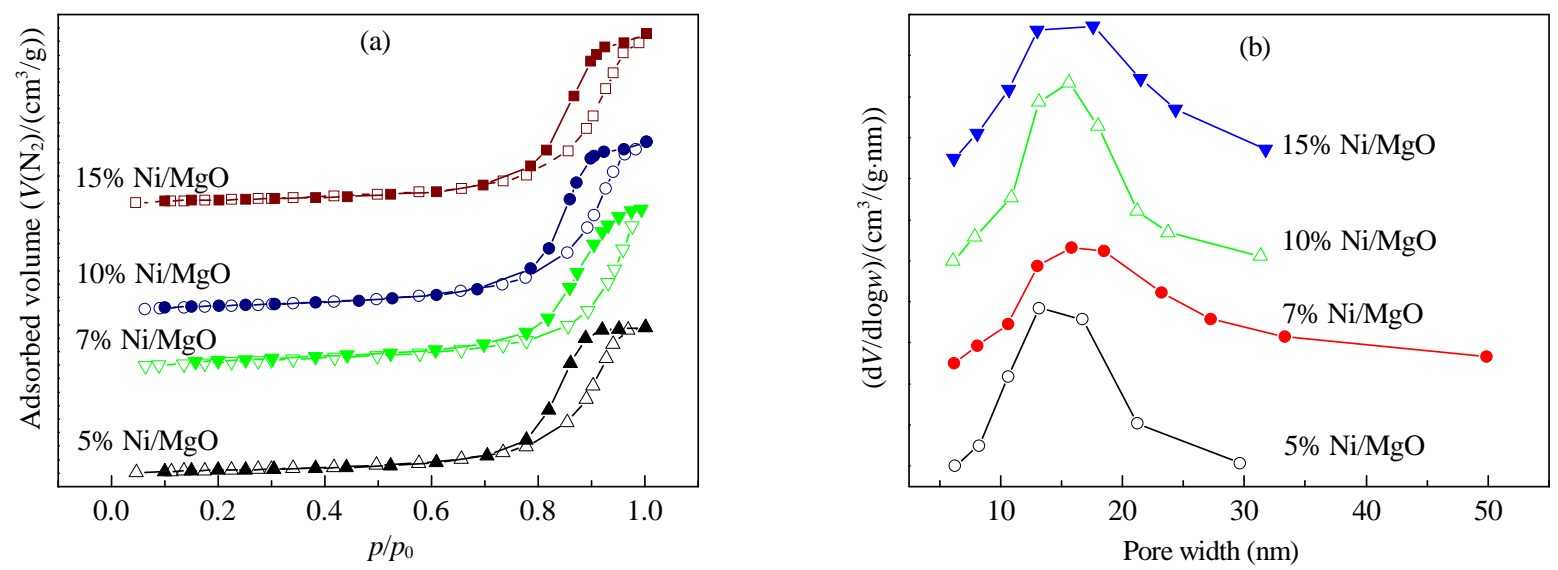

Fig. 2. $\mathrm{N}_{2}$ adsorption isotherms (a) and pore size distributions (b) of the $\mathrm{Ni} / \mathrm{MgO}$ catalysts.

pore size distribution of the samples is shown in Fig. 2(b). The samples had mesoporous structure with a pore size distribution in the range of $12-14 \mathrm{~nm}$.

The SEM images of the MgO sample calcined at $700{ }^{\circ} \mathrm{C}$ showed a plate shape and nanocrystalline structure (Fig. 3(a)). The SEM analysis also showed that the MgO consisted of irregularly shaped quasi-two dimensional micron-sized particles. The TEM analysis also confirmed that the MgO crystals were plate-like in shape (Fig. 3(b)).

Figure 4 presents the $\mathrm{H}_{2}$-TPR results of the catalysts. The TPR profiles of calcined catalysts showed a small reduction peak at around $500{ }^{\circ} \mathrm{C}$, which was due to some $\mathrm{Ni}^{2+}$ ions in a square pyramidal coordination in the outmost layer of the $\mathrm{MgO}$

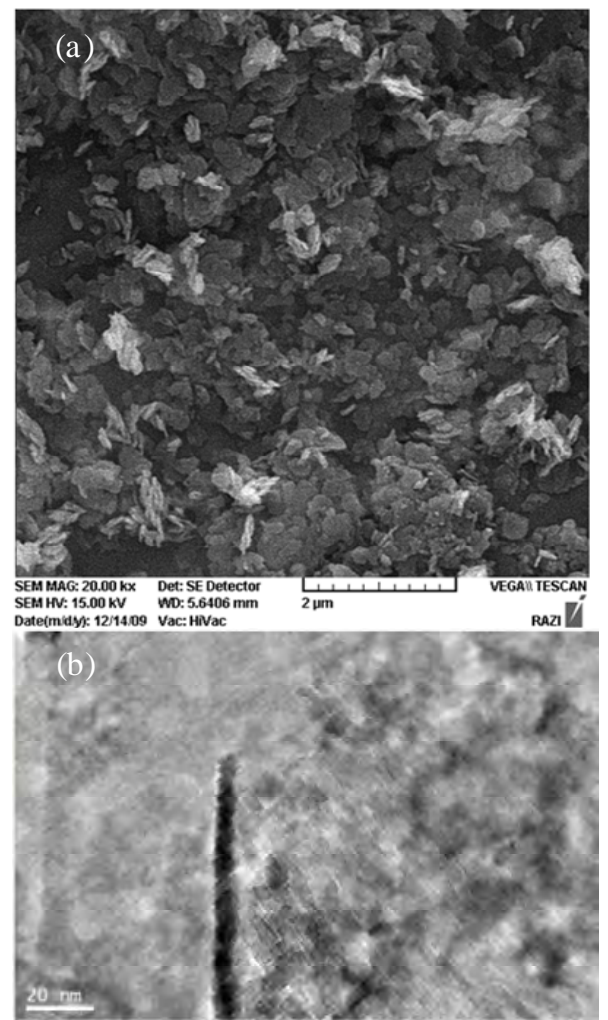

Fig 3. SEM (a) and TEM (b) images of the MgO support. structure. The major reduction peak was observed at a very high temperature, around $1000{ }^{\circ} \mathrm{C}$, which was ascribed to the reduction of $\mathrm{Ni}^{2+}$ ions located in the subsurface layers of the MgO lattice. This showed that there was a strong interaction between $\mathrm{NiO}$ and $\mathrm{MgO}$ and formation of a $\mathrm{NiO}-\mathrm{MgO}$ solid solution. In addition, the intensity of the first small peak at $500{ }^{\circ} \mathrm{C}$ was weaker in catalysts with lower nickel contents, indicating that most of the nickel was incorporated into the MgO structure to form a solid solution. The TPR results and analysis were in agreement with the XRD results, which showed the formation of a $\mathrm{NiO}-\mathrm{MgO}$ solid solution.

$\mathrm{CH}_{4}$ conversion over the $\mathrm{Ni} / \mathrm{MgO}$ catalysts with various nickel loadings at different reaction temperatures is shown in Fig. 5(a). The $\mathrm{CH}_{4}$ conversion increased with increasing reaction temperature. There was an increase in methane conversion with increasing $\mathrm{Ni}$ content up to $7 \%$. With increasing $\mathrm{Ni}$ content that was more than $7 \%$, the methane conversion decreased due to a lower nickel dispersion on the catalyst surface. This suggested that the higher Ni loading increases the Ni particle size and subsequently diminishes the active sites for $\mathrm{CH}_{4}$ conversion. Fig. 5(b) indicates that all the catalysts have stable activity at $700{ }^{\circ} \mathrm{C}$ during $6 \mathrm{~h}$ time on stream.

The effect of gas hourly space velocity (GHSV) on the catalytic performance of $7 \% \mathrm{Ni} / \mathrm{MgO}$ catalyst was investigated. The

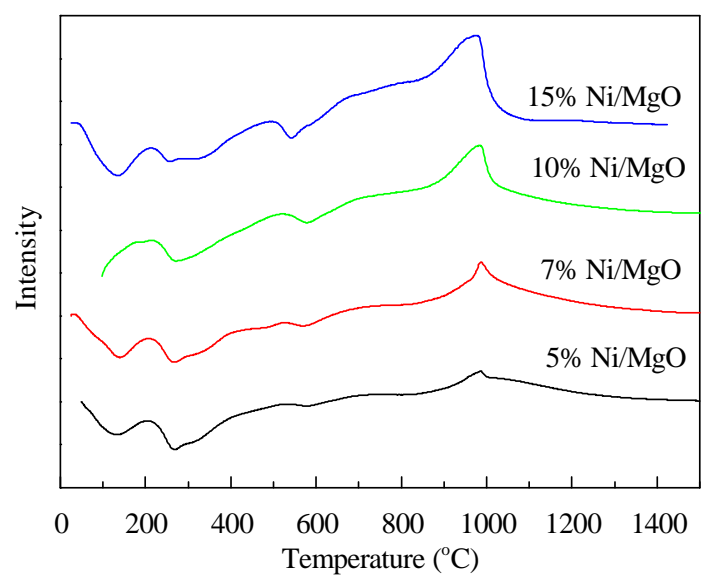

Fig. 4. $\mathrm{H}_{2}$-TPR profiles of the $\mathrm{Ni} / \mathrm{MgO}$ catalysts. 

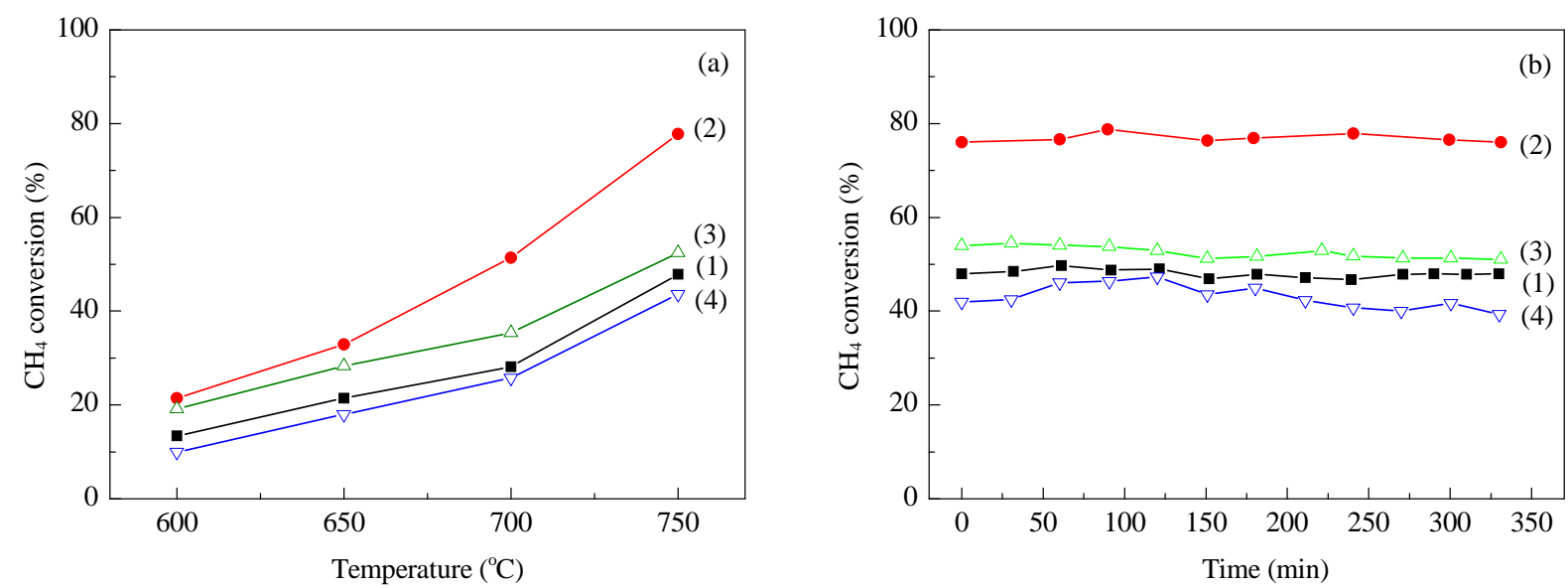

Fig. 5. $\mathrm{CH}_{4}$ conversion (a) and catalyst stability (b). (1) $5 \% \mathrm{Ni} / \mathrm{MgO}$; (2) 7\% Ni/MgO; (3) $10 \% \mathrm{Ni} / \mathrm{MgO}$; (4) $15 \% \mathrm{Ni} / \mathrm{MgO}$. $\mathrm{CH}_{4} / \mathrm{steam}=1 \mathrm{and} \mathrm{GHSV}=$ $3.6 \times 10^{4} \mathrm{ml} /(\mathrm{h} \cdot \mathrm{g})$.
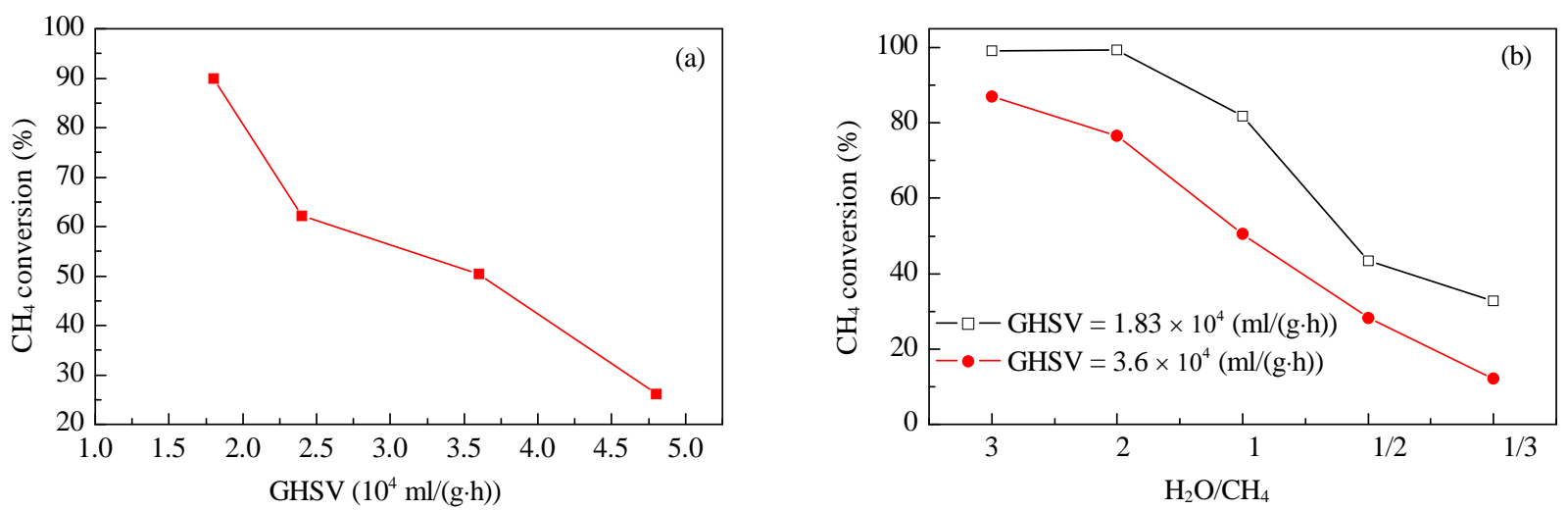

Fig. 6. Effect of GHSV (a) and $\mathrm{H}_{2} \mathrm{O} / \mathrm{CH}_{4}$ ratio (b) on the catalytic conversion of $7 \% \mathrm{Ni} / \mathrm{MgO}$ catalyst. Reaction temperature $=700^{\circ} \mathrm{C}$.

results are presented in Fig. 6(a). $\mathrm{CH}_{4}$ conversion decreased with increasing GHSV, because a larger GHSV gave less contact time.

In addition, the effect of the $\mathrm{H}_{2} \mathrm{O} / \mathrm{CH}_{4}$ ratio on the catalytic performance of the $7 \% \mathrm{Ni} / \mathrm{MgO}$ catalyst was investigated (Fig. 6(b)). Increasing the $\mathrm{H}_{2} \mathrm{O} / \mathrm{CH}_{4}$ ratio increased the methane conversion. This was due to the decreasing of the amount of oxidant $\left(\mathrm{H}_{2} \mathrm{O}\right)$.

Figure 7 shows the long term stability of the $7 \% \mathrm{Ni} / \mathrm{MgO}$ catalyst. The catalyst showed good catalytic stability during 50 h on stream.

Figure 8(b) shows the pore size distribution of spent catalysts after $6 \mathrm{~h}$ time on stream. Mesoporosity was still seen in the spent catalysts. However, the pore size distribution of the $7 \% \mathrm{Ni} / \mathrm{MgO}$ catalyst was shifted to larger pores after $50 \mathrm{~h}$ time on stream. The $\mathrm{N}_{2}$ isotherms were type IV with a large Type $\mathrm{H}_{3}$ hysteresis loop that is due to mesoporous structure (Fig. 8(a)). Furthermore, the specific surface area of the spent catalysts had decreased as compared to the fresh catalysts, as presented in Table 1. In addition, there was a decrease in pore volume and increase in the pore size of the catalysts after reaction.

The SEM analysis of the spent catalysts is shown in Fig. 9. The results revealed that deposited carbon increased with increasing nickel content, and the most amount of deposited carbon was observed on $15 \% \mathrm{Ni} / \mathrm{MgO}$.

The TPO profiles of the spent $\mathrm{Ni} / \mathrm{MgO}$ catalysts with different nickel loadings are shown in Fig. 10. The results showed an increase in the intensity and area of the peaks in the TPO profiles with increasing nickel content. The results indicated three kinds of carbon species on the catalyst surface after the steam reforming reaction. The first peak at $150-200{ }^{\circ} \mathrm{C}$ can be as-

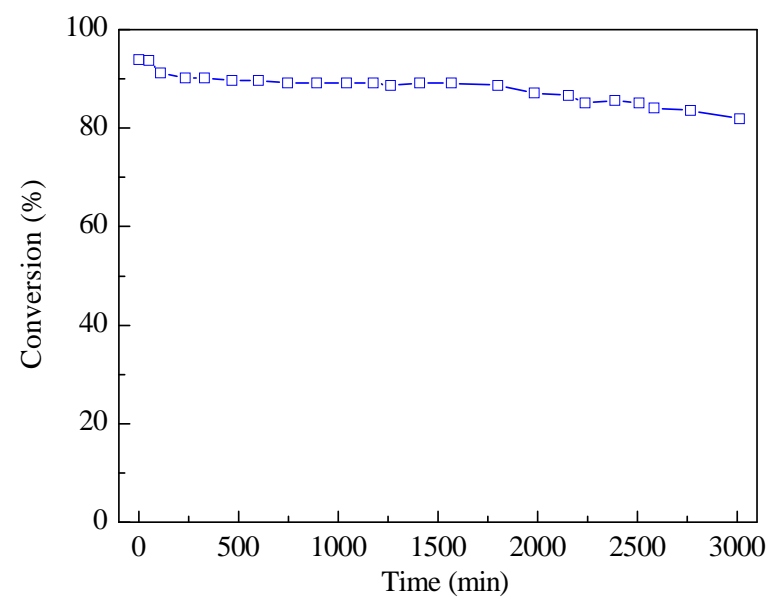

Fig. 7. Long term stability of $7 \% \mathrm{Ni} / \mathrm{MgO} . \mathrm{H}_{2} \mathrm{O} / \mathrm{CH}_{4}=1, \mathrm{GHSV}=1.83 \times$ $10^{4} \mathrm{ml} /(\mathrm{h} \cdot \mathrm{g})$, reaction temperature $=700^{\circ} \mathrm{C}$. 

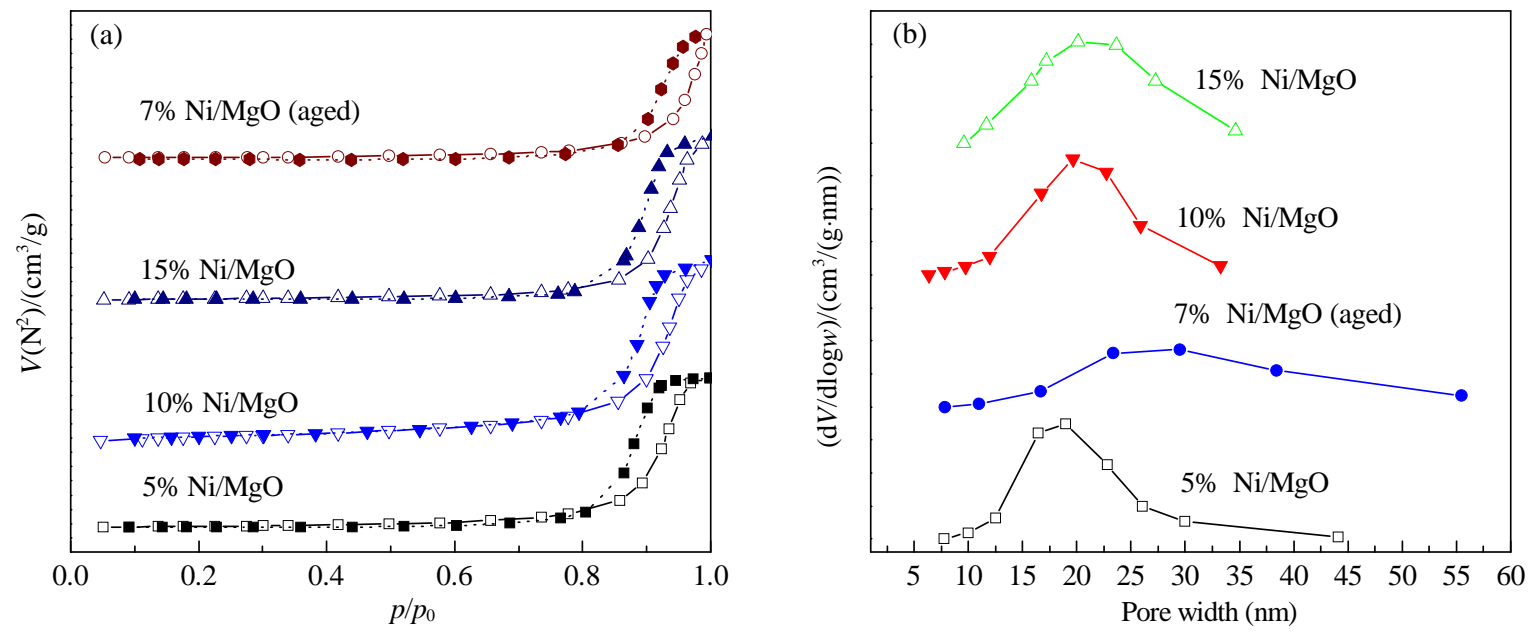

Fig. 8. $\mathrm{N}_{2}$ adsorption isotherms (a) and pore size distributions (b) of spent $\mathrm{Ni} / \mathrm{MgO}$ catalysts.
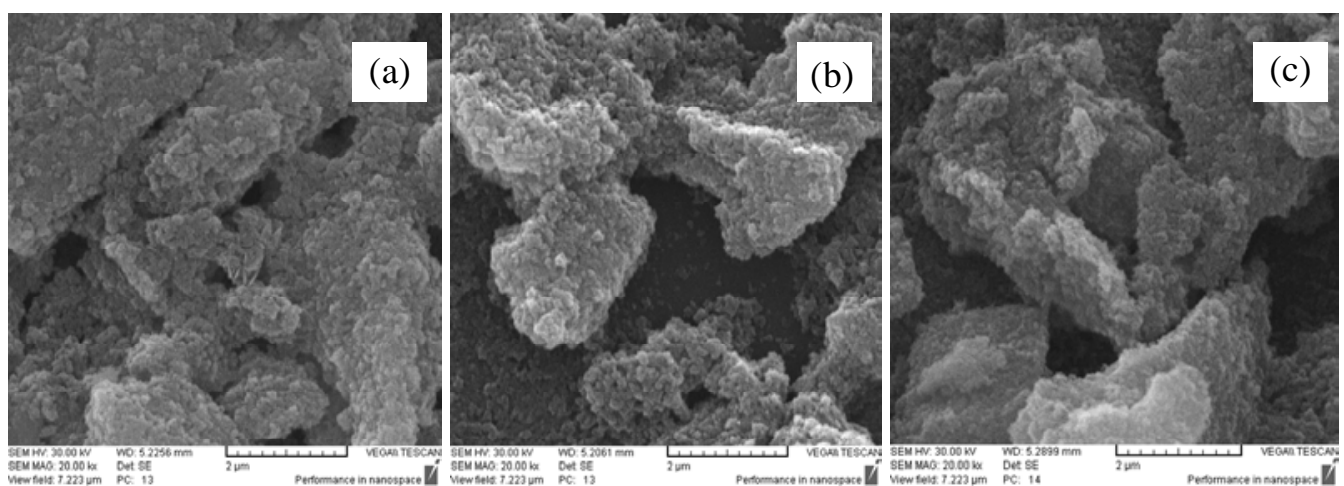

Fig. 9. SEM analysis of the spent $\mathrm{Ni} / \mathrm{MgO}$ catalysts with different nickel loadings. (a) 7\% Ni/MgO; (b) 10\% Ni/MgO; (c) 15\% Ni/MgO.

signed to superficial carbidic carbon $\left(\mathrm{C}_{\alpha}\right)[8,9,11]$. The second peak at $400{ }^{\circ} \mathrm{C}$ was assigned to amorphous carbon on the nickel site [12] and the third peak at temperatures higher than $500{ }^{\circ} \mathrm{C}$ was assigned to whisker-type carbon [12-15]. The most amount of carbon deposition was observed on the $15 \%$ $\mathrm{Ni} / \mathrm{MgO}$ catalyst.

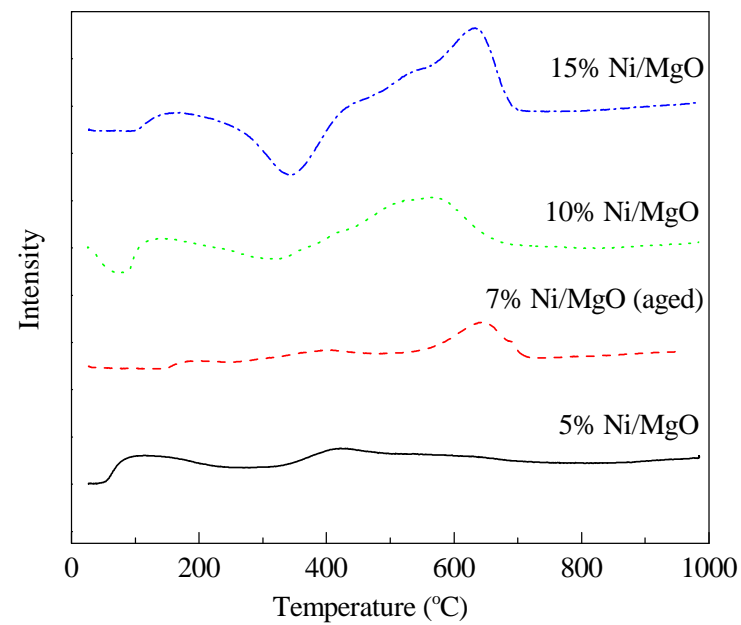

Fig. 10. TPO analysis of spent $\mathrm{Ni} / \mathrm{MgO}$ catalysts with different nickel loadings.

\section{Conclusions}

Nanocrystalline $\mathrm{MgO}$ with a plate-like shape that had a relatively high surface area and highly defective surface structure was employed as the support of Ni catalysts for steam reforming. The strong interaction between $\mathrm{NiO}$ and $\mathrm{MgO}$ in the solid solution inhibited the reduction of $\mathrm{NiO}$. Thus, relatively small and highly dispersed metallic Ni particles were obtained in the reduction treatment. The metal surface was more resistant towards coke formation because the ensemble size necessary for carbon formation is larger than the ensemble size necessary for methane reforming. An increase in nickel content gave an increased amount of deposited carbon. The $7 \% \mathrm{Ni} / \mathrm{MgO}$ catalyst was very effective in methane steam reforming and exhibited stable activity up to 3000 min of reaction.

\section{References}

[1] Stelmachowski M, Nowicki L. Appl Energy, 2003, 74: 85

[2] Hu Y H, Ruckenstein E. Catal Rev-Sci Eng, 2002, 44: 423

[3] Guo J J, Lou H, Zheng X M. Carbon, 2007, 45: 1314

[4] Hu Y H. Catal Today, 2009, 148: 206

[5] Climent M J, Corma A, Iborra S, Mifsud M. J Catal, 2007, 247: 223

[6] Naito S, Tanaka H, Kado S, Miyao T, Naito S, Okumura K, Kunimori 


\section{Graphical Abstract}

Chin. J. Catal., 2013, 34: 1443-1448 doi: 10.1016/S1872-2067(12)60606-8

\section{A nanocrystalline $\mathrm{MgO}$ support for $\mathrm{Ni}$ catalysts for steam reforming of $\mathrm{CH}_{4}$}

Mahmood ANDACHE, Mehran REZAEI *, Mansour KAZEMI MOGHADAM

Islamic Azad University, Iran; University of Kashan, Iran; Iran University of Science and Technology, Iran

\section{High stable catalyst with low carbon formation}
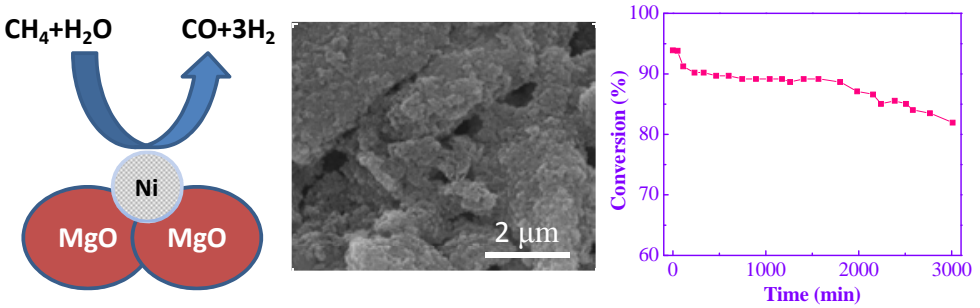

A 7\% $\mathrm{Ni}$ catalyst supported on mesoporous nanocrystalline MgO showed high catalytic stability and low degree of carbon formation in steam reforming of methane for syngas production.

K, Tomishige K. J Catal, 2008, 259: 138

[7] Xu B Q, Wei J M, Wang H Y, Sun K Q Zhu Q M. Catal Today, 2001, 68: 217

[8] Rezaei M, Meshkani F, Biabani-Ravandi A, Nematollahi B, Ranjbar A, Hadian N, Mosayebi Z. Int J Hydrogen Energy, 2011, 36: 11712

[9] Hadian N, Rezaei M, Mosayebi Z, Meshkani F. J Nat Gas Chem, 2012, 21: 200

[10] Meshkani F, Rezaei M. J Nat Gas Chem, 2011, 20: 198

[11] An L, Dong C Q, Yang Y P, Zhang J J, He L. Renew Energy, 2011, 36:
930

[12] Nematollahi B, Rezaei M, Khajenoori M. Int J Hydrogen Energy, 2011, 36: 2969

[13] Mosayebi Z, Rezaei M, Biabani-Ravandi A, Hadian N. Int J Hydrogen Energy, 2012, 37: 1236

[14] Rezaei M, Alavi S M, Sahebdelfar S, Bai P, Liu X M, Yan Z F. Appl Catal B, 2008, 77: 346

[15] Koo K Y, Roh H S, Seo Y T, Seo D J, Yoon W L, Park S B. Appl Catal A, 2008, 340: 183 